\title{
Use of Reflective Practices on Teaching-Learning in Distance Education
}

\author{
Dr. Uzma Murad Panhwar \\ Department of EMS, University of Sindh Jamshoro \\ uzma_panhwar@yahoo.com \\ Muhammad Farshad \\ $\mathrm{PhD}$ Scholar \\ School of Foreign Languages, Central China Normal University, China \\ Zohran Jumani \\ M. Phil Scholar, Iqra University
}

\begin{abstract}
This study is aimed at examining the use of teacher reflective practices in future professional development. The research was conducted to assess the effectiveness of educators' reflective behaviors on prospective teachers. After completing their under-graduation/ graduation degree from the distance teacher education programs, how much they will be professionally developed to use reflective practices effectively. Here, particularly the effectiveness of reflective practices of teacher educators for the professional development of future teachers has been investigated. For this survey, the researcher has used a five-point Likert scale, interview, classroom observation, and one-way Chi-square test. The study concludes with recommendations and implications based on the findings. For this investigation, the population is all the distance teacher educators' program from all the public universities in Sindh. The researcher selected 595 prospective teachers as a sample purposefully and 32 teacher educators for classroom observation.
\end{abstract}

Keywords: Reflective Practices, Teaching-Learning, Distance Education.

\section{Introduction}

The main purpose of education is to bring change in human behavior. A person considers new ideas, improves their thinking, establishes tests and sensitivities, and encourages change in other ways, which are the essence of reflection. Karen et al (1994, p. 19) Reflective practice and often misleading reflection are not an isolated or easy process of meditation. Rather, reflecting practice, which is the most successful joint effort, is a complex, demanding, and frequently experienced process.Learning is as old as human history. It is a perfect activity to teach a student to be curious and cautious with checks and balances, according to Paolini (2015) as, effective educators promote student learning using discussion, collaborative learning, compassion, and student concern. The lack of precise observation has a less significant effect on students' academic performances, emphasized Lambidhi (2015). These lines show that reflective practice and 
reflection are often combined and are almost as important as meditation or thought, but the two differ at certain points as well. It gives a specific sense to practice in the term. Reflective practice is a process that aims to change in behavior, which is possible not only through the application of traditional professional development methods but also requires a very practical and comprehensive form of professional development. This begins with "self-awareness" of the activity itself that creates opportunities for professional growth and this self-awareness is a type of job or business responsibility or commitment that begins with a thinking person and is a process of cooperation. In this sense, Dewey (1933, p. 6) maintained the constructive, lasting and serious consideration, as well as a further reflection on the roots of the reflective activities of Dewey's reflection, of any value or conclusion supported by his intellectual nature.

\section{Literature Review}

This reflective practice begins with a feeling of openness, uncertainty, a sense of deception, and ends with decisions or actions. These "uncertainties" and problems apply to the experience generated under certain circumstances rather than to professionals. Professionals have to build challenges or difficulties, partly based on their knowledge base and, in one case. In 1987 Donald Schon $(2000$, p. 1) introduces the idea of reflection, which refines art or work practice in a specific discipline and main processes. Moreover, Ferraro has a little bit different approach towards reflective practices, he believes the subject's reflective practice recognizes the balance between practitioners and effective practice.

Biggs' writing (2003, p. 7) Learning new strategies is like getting a fish for food every day. Instead, reflective practice is to provide a network of fish every day, for the rest of your life. Teachers and students also learn their experiences through reflection. Teachers who are serious practitioners can solve the challenges and difficulties they encounter in teaching. On the other hand, students will continue to be educated as serious professionals, future teachers and teacher educators. Students not only needs to establish a faculty of critical thinking but they must also look at their teaching methods. A duty can be fulfilled and measured not only through the recognition of responsibility but also through the desire to be rational. Through independent student activities, the responsible person can create a sense of responsibility and contribute to the growth of responsibility. Skill theory is a model of reflective practice that encourages students to actively cooperate with others and with themselves. The British Center for Legal Education (2003, p. 3) states: Teamwork also helps increase knowledge and education because people are accountable to 
the community and allow groups to assess their strengths and weaknesses. Zahoo (2003: 4) writes that: "The structured and supportive processes of the individual represent his plans for learning, success, achievement, and development." Reflective practice is a method that helps prepare for family selfcriticism, education, and professional development.

\subsection{Objectives}

Following were the objectives of study:-

1. Analyze the use of reflective practices and their effect on the distance learning system.

2. To give suggestions based on research findings regarding the use of reflective practices.

\subsection{Research Question}

Will the reflective practices of teacher educators affect future professional progress?

\subsection{Hypothesis}

Ho. Reflective practices in distance education have no significant effect on the teachinglearning program.

\section{Methodology}

Data was piloted and validated. The reliability of the data can be justified by the Cronbach's Alpha was 0.710 for 42 items. The researcher developed the following research tools to collect data.

1. Prospective teacher questionnaire

2. Interview with prospective teacher/teacher educator

3. Procedure for classroom observation

\subsection{Research Design}

Mix Method Research (MMR) is used in the study. The mixed-method research design widely accepted, and has been considered and used a lot in the past decade. MMR research design explores a research problem in several ways. By combining qualitative and quantitative methods, multiple data collection methods, and multiple different types of tools and samples are available. This called the Mix Method, as a social investigation, according to Greene (2006). The researcher built in-house research tools to meet the goal. A mixed research design approach follows special steps to evaluate, evaluate, interpret, and process, under particular conditions, the knowledge obtained from the various actors in a single study by the general population. 


\subsection{Population and Sampling}

All the distance education programs in Sindh comprised the population of the research, including teachers, professors, and students from all the universities of the public sector. The sample was taken from the population using an intentional sampling technique.

Table 1. Review of Teacher Educators

\begin{tabular}{|c|c|c|c|c|c|c|}
\hline S. No & Urban & Male & Female & Rural & Male & Female \\
\hline 1 & Hyderabad & 2 & 2 & Sanghar & 2 & 2 \\
\hline 2 & Nawabshah & 2 & 2 & Umerkot & 2 & 2 \\
\hline 3 & Mirpur Khas & 2 & 2 & Mithi & 2 & 2 \\
\hline 4 & Malir Karachi & 2 & 2 & Shadadpur & 2 & 2 \\
\hline \multicolumn{7}{|c|}{ Total } \\
\hline
\end{tabular}

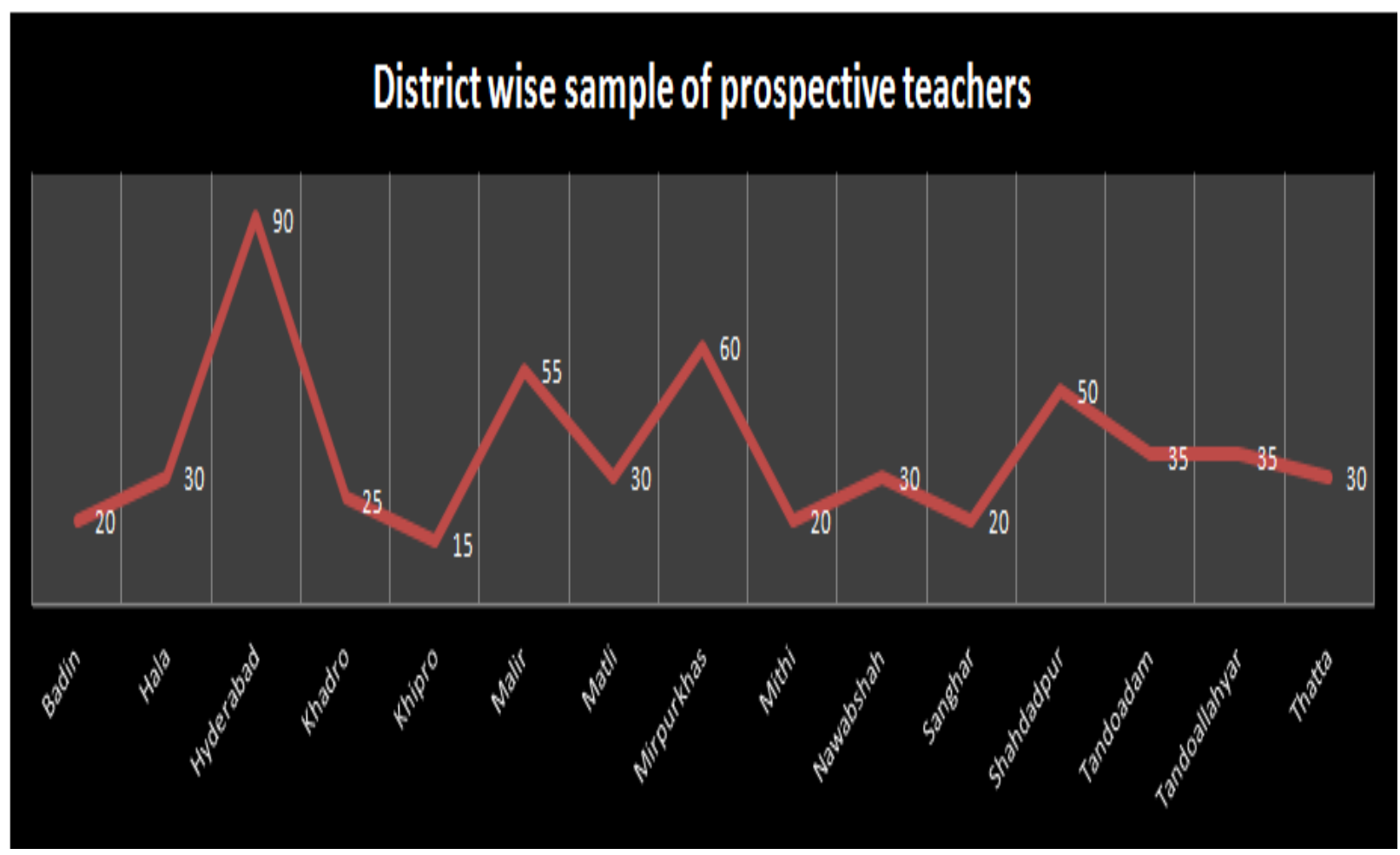




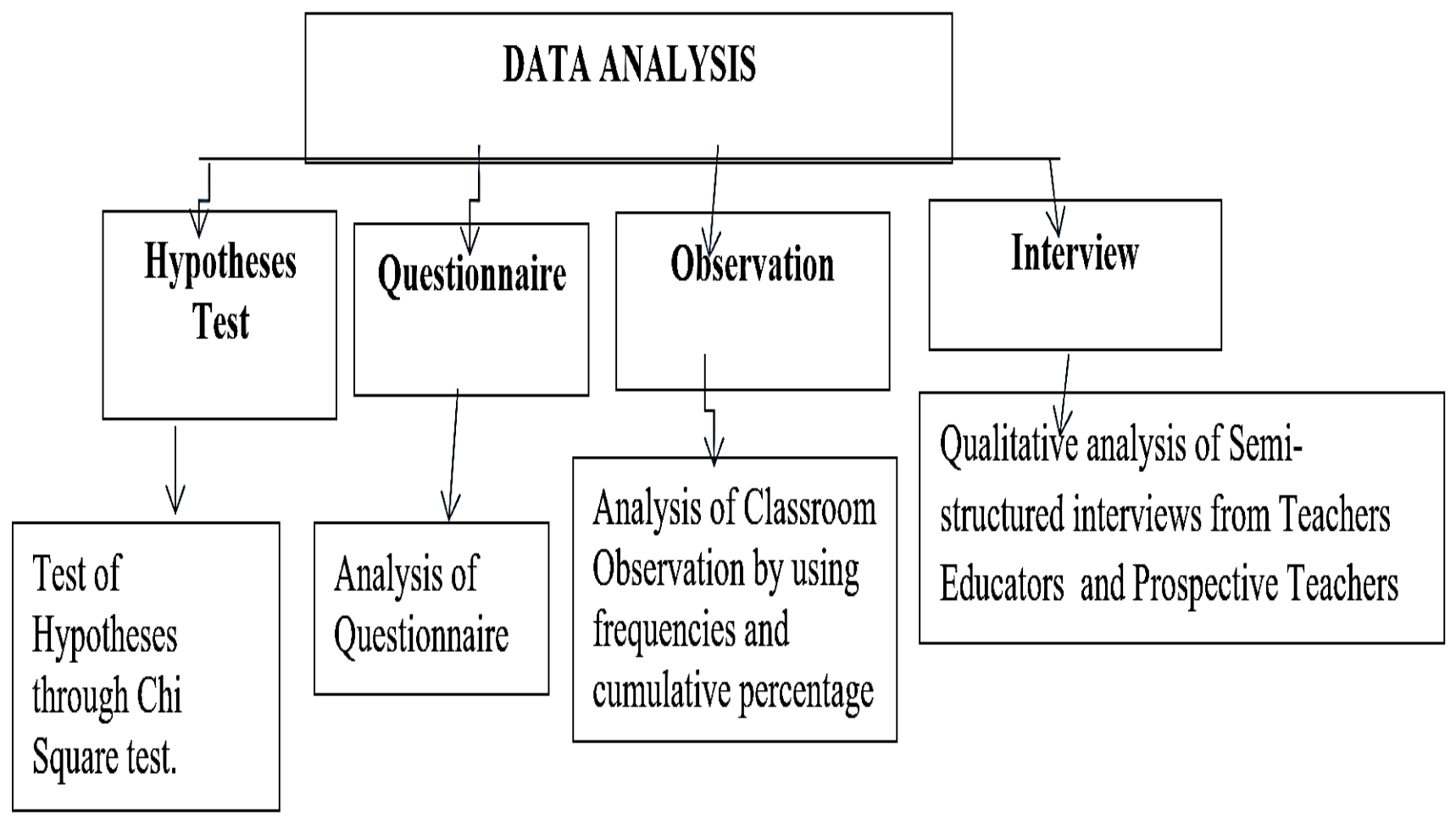

\subsection{Problems Analysis}
a) Test Statistics: Chi Squire
b) $\alpha=0.05$
c) $\mathrm{H}_{0}: \mathrm{f}_{1}=\mathrm{f}_{2}$
d) $\mathrm{H}_{1}: \mathrm{f}_{1} \neq \mathrm{f}_{2}$

$$
X^{2}=\sum \frac{(O-E)^{2}}{E}
$$

e) $\quad \mathrm{H} 0$ indicates that the observed $(\mathrm{O})$ and expected (E) frequencies are not substantially different.

f) Decision rule: If $\mathrm{p}$ is $\leq \alpha, \mathrm{H} 0$ is rejected; otherwise, it is 0 . Otherwise, please refuse. This is a two-tailed test. (Chi-square test is always two tails)

g) Conclusion: Decide whether to reject $\mathrm{H} 0$. 
Table 2. Hypothesis

\begin{tabular}{|l|c|c|c|}
\hline Level & Observed & Expected & Residual \\
\hline Strongly Agree & 137 & 119 & 18 \\
\hline Agree & 110 & 119 & -9 \\
\hline Uncertain & 105 & 119 & -14 \\
\hline Disagree & 115 & 119 & -4 \\
\hline Strongly Disagree & 128 & 119 & 9 \\
\hline Total & & 595 & \\
\hline
\end{tabular}

Table3. Test Statistics

\begin{tabular}{|l|c|}
\hline Test & Hypothesis \\
\hline Chi-Square & $5.866 \mathrm{a}$ \\
\hline Df & 4 \\
\hline Asymp. Sig. & 0.209 \\
\hline
\end{tabular}

$(.0 \%)$ The expected frequency is less than 5 . The expected minimum frequency of the unit is 119.0. If the value of $\mathrm{p}(.0209)$ is less than or equal to the level of $\alpha$, then we can reject H0. The table shows that in the current situation, the p-value (.0209) is greater than $\alpha(.05)$, so we cannot reject H0. In other words, there is insufficient evidence to show that teachers' reflection activities in training have any impact on their professional abilities. Frequency of reflective practice obtained from observing instruments.

Table 4. The Exploitation of Reflective Practice

\begin{tabular}{|c|c|c|c|c|c|c|}
\hline Level & Never & Rarely & Sometimes & Usually & Always & Total \\
\hline Frequency & 11 & 11 & 3 & 4 & 3 & 32 \\
\hline Percent & 34.4 & 34.4 & 9.4 & 12.5 & 9.3 & 100 \\
\hline Valid Percent & 34.4 & 34.4 & 9.4 & 12.5 & 9.3 & 100 \\
\cline { 1 - 5 } $\begin{array}{c}\text { Cumulative } \\
\text { Percent }\end{array}$ & 34.4 & 68.8 & 78.1 & 90.6 & 100 & 100 \\
\hline
\end{tabular}




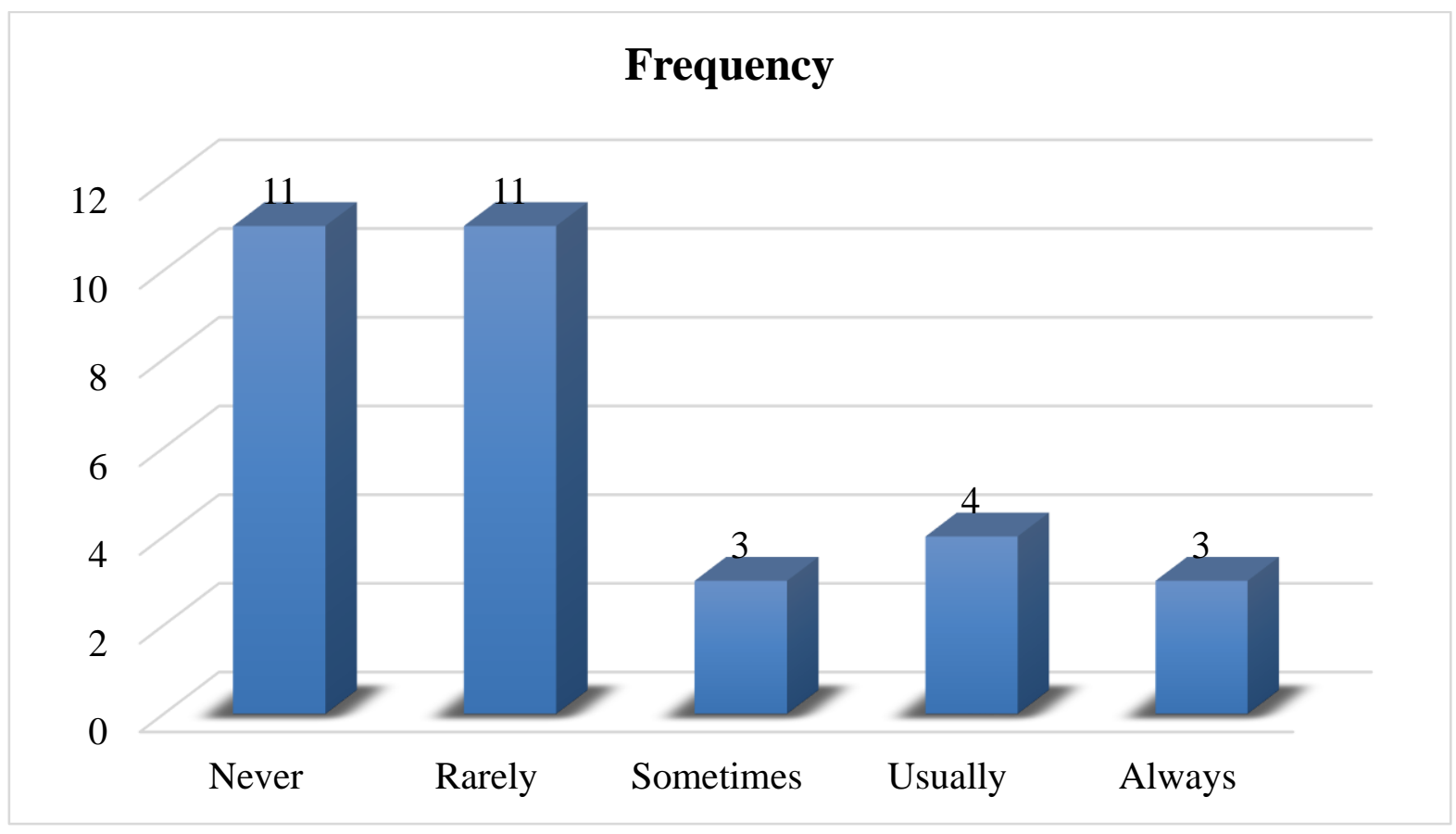

The observations in this statement are related to the use of reflective practices in the teaching process, especially in distance educations programs in Sindh. The researchers pointed out that $34.4 \%$ of teacher educators have never reflected, and $34.4 \%$ have participated in this practice. It was found that only $9.4 \%$ of teacher educators emphasize self-reflection. While they now saw and addressed teaching differences. Instructor educators were also found to take pride in focusing on their teaching and prove to be an efficient teacher. Reflection on the potential success of the teacher is also very small.

Table 5. Summary of the Findings / Conclusion and Recommendation

\begin{tabular}{|c|c|c|c|c|c|c|}
\hline \multirow[b]{2}{*}{ Questions } & \multirow[b]{2}{*}{$\begin{array}{c}\text { Filled by the } \\
\text { Teacher }\end{array}$} & \multirow{2}{*}{$\begin{array}{c}\text { Distance } \\
\text { Education } \\
\text { Center } \\
\text { Classroom } \\
\text { Observation }\end{array}$} & \multicolumn{2}{|c|}{ Interviews } & \multirow[b]{2}{*}{ Conclusion } & \multirow[b]{2}{*}{ Recommendations } \\
\hline & & & $\begin{array}{c}\text { Teacher } \\
\text { Educators }\end{array}$ & $\begin{array}{c}\text { Prospective } \\
\text { Teachers }\end{array}$ & & \\
\hline Will teacher & The prospective & It has been & Most & Future & It has been & Teacher educators \\
\hline educators' & teacher did not & observed & teacher & teachers & concluded & are recommended \\
\hline proactive & mind the & that teacher & educators & agreed after & that teaching & to use reflective \\
\hline activities & reflection. & & think that a & extensive & instructors & practices to have a \\
\hline
\end{tabular}




\begin{tabular}{|c|c|c|c|c|c|c|}
\hline \multirow[b]{2}{*}{ Questions } & \multirow[b]{2}{*}{$\begin{array}{c}\text { Filled by the } \\
\text { Teacher }\end{array}$} & \multirow{2}{*}{$\begin{array}{c}\text { Distance } \\
\text { Education } \\
\text { Center } \\
\text { Classroom } \\
\text { Observation }\end{array}$} & \multicolumn{2}{|c|}{ Interviews } & \multirow[b]{2}{*}{ Conclusion } & \multirow[b]{2}{*}{ Recommendations } \\
\hline & & & $\begin{array}{c}\text { Teacher } \\
\text { Educators }\end{array}$ & $\begin{array}{c}\text { Prospective } \\
\text { Teachers }\end{array}$ & & \\
\hline $\begin{array}{c}\text { affect future } \\
\text { teachers' } \\
\text { professional } \\
\text { developmen } \\
\text { t? }\end{array}$ & & $\begin{array}{c}\text { not habitual } \\
\text { users of } \\
\text { reflective } \\
\text { practices. } \\
\text { They are not } \\
\text { receiving } \\
\text { feedback } \\
\text { from future } \\
\text { teachers to } \\
\text { know their } \\
\text { teaching } \\
\text { effect. }\end{array}$ & $\begin{array}{c}\text { teacher } \\
\text { educator } \\
\text { should be } \\
\text { aware of } \\
\text { the } \\
\text { importance } \\
\text { and effect } \\
\text { of their } \\
\text { success. } \\
\text { However, } \\
\text { time } \\
\text { cannot be } \\
\text { saved for } \\
\text { these tasks } \\
\text { due to a } \\
\text { lack of } \\
\text { resources. }\end{array}$ & $\begin{array}{l}\text { research on the } \\
\text { subject that } \\
\text { their teachers } \\
\text { are not using } \\
\text { reflective } \\
\text { practices. } \\
\text { They offer } \\
\text { mainly verbal } \\
\text { feedback } \\
\text { about our } \\
\text { presentations. }\end{array}$ & $\begin{array}{c}\text { and } \\
\text { prospective } \\
\text { teachers are } \\
\text { not } \\
\text { sufficiently } \\
\text { understood } \\
\text { and engaged } \\
\text { in reflective } \\
\text { practices. } \\
\text { Teachers can } \\
\text { increase the } \\
\text { quality of } \\
\text { teaching } \\
\text { through the } \\
\text { use of } \\
\text { reflective } \\
\text { methods. }\end{array}$ & $\begin{array}{c}\text { high impact on } \\
\text { their teachings; } \\
\text { they should receive } \\
\text { regular feedback } \\
\text { from future } \\
\text { teachers and their } \\
\text { colleagues about } \\
\text { their teachings. } \\
\text { Distance-education } \\
\text { stakeholders will } \\
\text { coordinate teacher } \\
\text { training on the } \\
\text { successful use of } \\
\text { reflective activities. }\end{array}$ \\
\hline
\end{tabular}

\section{References}

Osterman, K. A. R. E. N., \& Kottkamp, R. O. B. E. R. T. (1994). Rethinking professional development. Improving Educational Management through research and consultancy, 4657.

Prabhu, R. S. (2014). U.S. Patent Application No. 13/720,564.

Paolini, E., Liva, G., \& Chiani, M. (2015). Coded slotted ALOHA: A graph-based method for uncoordinated multiple access. IEEE Transactions on Information Theory, 61(12), 68156832. 
Paolini, A. (2015) Enhancing teaching effectiveness and student learning outcome. The Journal of effective teaching, 15 (1), 20-33

Dewey, J. (1933). How we think: A restatement of the relation of reflective thinking to the educative process. DC Heath.

Lane, E. S. and Harris, S. E. (2015). A new tool for measuring student behavioral engagement in large university classes. Journal of College Science Teaching, 44(6), 83-91

Ferraro, J. M. (2000). Reflective practice and professional development. ERIC Clearinghouse on Teaching and Teacher Education.

Schön, D. (1987). A.(1987):“Educating the Reflective Practitioner”. San Franscisco: Jossey-Base.

Biggs, J. (2003). Teaching for quality learning at university: What the student does (2nd edn.; Buckingham: SRHE \& Open University Press).

Combs, A., Blume, R., Newman, A., \& Wass, H. (1974). The professional education of teachers: A humanistic approach to teacher education.

Fry, H., Ketteridge, S., \& Marshall, S. (2008). A handbook for teaching and learning in higher education: Enhancing academic practice. Routledge.

Jumani, N. B., Baloch, I. H., Khan, S. B., \& Nagheen, A. Paradigm of Reflective Practices Pravailng in Teacher Training Programme Through Distance Education in Pakistan.

Greene, J. C. (2006). Towards a methodology of mixed methods social inquiry. Research in the Schools, 13(1), 93-98. 